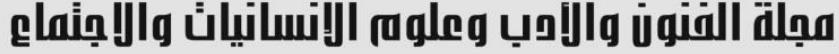

Journal of Arts, Literature, Humanities and Social Sciences

www.jalhss.com

Volume (65) - February 2021

العدد (65) - فبراير 2021

\section{Plantation Landscapes and the Colonial Legacy in V. S. Naipaul's The Middle Passage}

\author{
Samar H. Aljahdali \\ Assistant professor in the Department of English - College of Languages and \\ Translation - University of Jeddah - Kingdom of Saudi Arabia \\ Email: shaljahdali@uj.edu.sa
}

\begin{abstract}
The negotiation of the politics and poetics of plantation landscapes has recently become a major concern in postcolonial studies (DeLoughrey 2015, 2011). With a particular focus on V. S. Naipaul's The Middle Passage: The Caribbean Revisited (2002), this paper examines the historical signification and power politics of the sugarcane plantation landscapes in the Caribbean islands. Within the emergent field of environmental humanities, the study draws on E. Glissant (1999) and E. Deloughrey $(2001,2015)$ for useful conceptions in relation to the interplay of the natural and the human, the material and the discursive as mutually constitutive to the representation of the land. Naipaul's literary configuration of the plantation landscapes in the West Indies represents the ruptures and discontinuities inflicted by European colonialism. In this particular geopolitical and discursive context, human and non-human elements of landscape and seascape form a dialectical relation that continue to assert the agency of colonial and postcolonial interventions in the palimpsest of the Caribbean topography.
\end{abstract}

Keywords: Caribbean postcolonial literature, sugarcane plantation, landscape, V. S. Naipaul, The Middle Passage. 


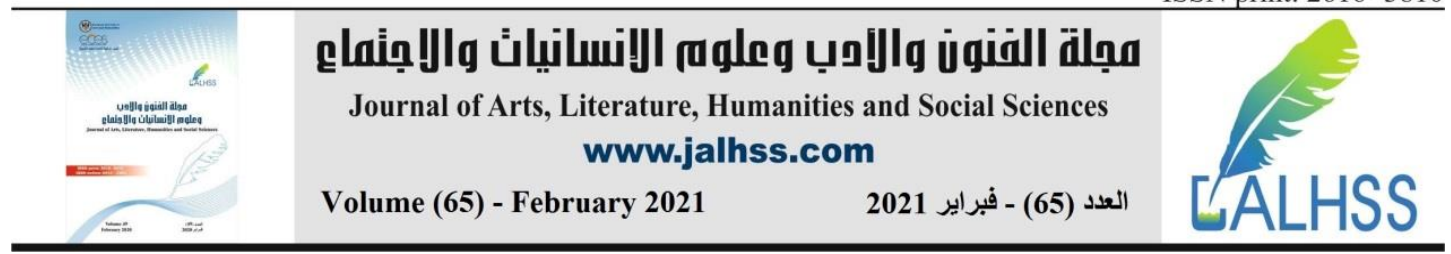

\section{Plantation Landscapes and the Colonial Legacy in V. S. Naipaul's The Middle Passage}

"Our landscape is its own monument: its meaning can only be traced on the underside. It is all history." (E. Glissant, Caribbean Discourse 1999, p. 11)

" 'Cane is bitter' is the title of a story by Samuel Selvon and might well be the epigraph of a history of the Caribbean." (V. S. Naipaul, The Middle Passage 2002, p. 56)

\section{Introduction:}

How can sugarcane be 'bitter'? Is it the bitterness entrenched in the colonial history of sugar plantation and industry? or the bitterness emanating from the ecological rupture associated with this colonial practice? Glissant (1999) has contributed to the conceptualization of the agency of landscape in Caribbean literature and the historicity inherent in its multivocal depictions, encouraging local writers to reinscribe the dialectics of landscape and power. With particular focus on V. S. Naipaul's travel narrative, The Middle Passage (2002--first published in 1962), this paper offers a cultural materialist exploration of representations of the Caribbean plantation landscapes. It sketches ways to understand the (neo)colonial legacy of the plantation as a mode of production as well as the agency of postcolonial Caribbean literary writing in unsettling the colonial framings of this ecology.

\section{Literature Review:}

The negotiation of the politics and poetics of plantation landscapes has recently become a major concern in postcolonial studies. While broadening the historical, thematical, and geographical scope of its endeavor, the essay collection edited by E. DeLoughrey \& G. Handley (2011) contribute to discourses on postcolonial ecologies, emphasizing that questions of postcolonialism and ecocriticism are inextricably intertwined. In 2015, a new Routledge edited collection was released, bringing a plethora of nuanced postcolonial approaches to discuss issues at the intersection of global ecologies and environmental humanities (E. DeLoughrey \& etal (2015). These critical engagements among others came in response to the need for postcolonial interventions in eco-criticism. L. Perfetti (2007) notes a conspicuous marginalization of the ecological question in postcolonial studies of Caribbean literature while more scholarly attention has been given to the social and cultural repercussions of slavery in the region. With particular focus on Simone SchwartzBarts's Francophone novel, translated as The Bridge of Beyond, Perfetti discusses both the plantation and the garden as forms of colonial and postcolonial spaces respectively. The plantation, in the novel, is frequently referred to as the factory, and 


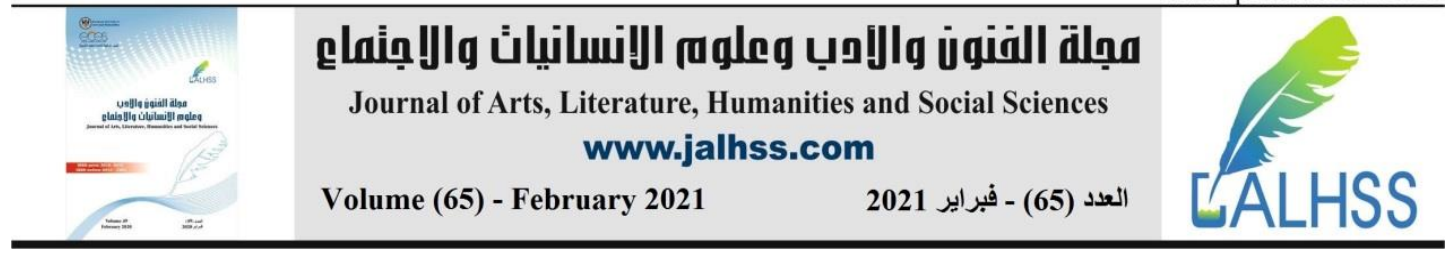

this designation, contends Perfitti (2007), "distances it from the connotations of natural fertility that 'plantation' would suggest" (p. 94). The personal home garden in the Caribbean houses, however, signifies a site of resistance and reconnection to the land. This paper extends this argument by exploring the plantation as a colonial space that marks the continuity of colonial legacy in the Caribbean.

With particular focus on the aesthetics of decay, L. Paravisini-Gebert (2015) explores Caribbean artistic representations of/with bagasse, the debris of sugar plantation. The works of material artists and painters including Charles Campbell and Atelier Morales among others reveal the colonial exploitation of humans and nature, as well as the environmental costs of sugar plantations. Bagasse was not only represented, but also used as a natural material in Caribbean artistic production, signifying both the ruination inflicted by sugar plantation and the native's desire to invest that debris in local and postcolonial visual arts.

E. DeLoughrey (2004) examines Caribbean literary representations of the land including Jamaica Kincaid's My Garden and Senior's poetic collection, Gardening in the Tropics, to explore the relation between European colonization and Caribbean island ecology. Through literary reconfigurations, DeLoughrey (2004) argues, Caribbean writers emphasize the inextricable entanglement of human and natural histories in the Caribbean islands, which has turned the land into a palimpsest where traces of pre-colonial, colonial, and postcolonial inscriptions intervene, revealing the interplay of power and landscape in the region.

This interest in the complex historicity of the Caribbean islands landscapes has been shared by M. Hauser and D. Hicks (2007) in their study of postcolonial archaeology. Bringing together material and ideational approaches of historical archaeology and postcolonialism, the study decentralizes mainstream trends of world historical archaeology. Landscapes archaeology, Hauser and Hicks (2007) argue, should open up its tools to multiple scales of analysis in order to develop a postcolonial archaeology that would counteract the 'terra nulli' ideology of the precolonial past. Drawing attention to the historicity of plantation landscapes, they highlight shifts from mapping colonial power and domination to articulation of resistance and alternative voices.

Drawing on Gilroy's and Glissant's theories, G. De Ferrari (2012) argues that the ship and the plantation form two chronotopes peculiar to "a Caribbean mode of existence based on relationality" (p. 187). Both the ship and the plantation signify enclosure, unharmonious cohabitation and, more importantly, the violence of history. While the ship, "a micro-political system in motion," is associated with the infamous history of slavery and the enforced voyage through the middle passage towards the Caribbean islands, the plantation signifies a "violent enclave of multicultural togetherness" (p. 191). 


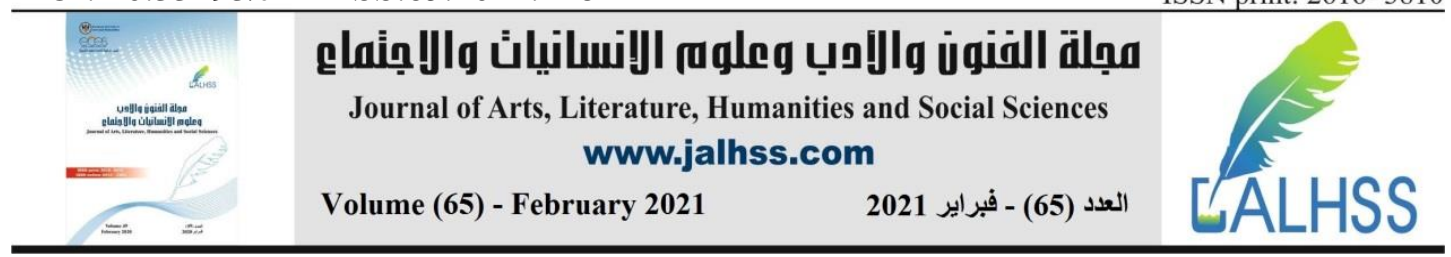

\section{Theoretical framework}

With a particular focus on V. S. Naipaul's The Middle Passage (2002), this paper contributes to the existing literature by examining the historical signification and power politics of the plantation landscapes in the Caribbean islands. It situates itself in the emergent field of environmental humanities also known as ecological humanities in relation to the postcolonial framework. It emphasizes the centrality of narrative to reposition knowledge from below, and destabilizes the power structure that inscribed it. The study draws on E. Glissant (1999) and E. DeLoughrey (2001, 2015) for useful conceptions in relation to the natural and the human, the material and the discursive as mutually constitutive to the land.

E. Glissant (1999) theorizes the emergence of landscape as "a full character" and its agency in the making and remaking of history by colonial and postcolonial power politics, pointing to the fissures and the multiple layers of history printed on the Caribbean landscapes (p. 105). According to Glissant (1999), "[t]he individual, the community, the land are inextricable in the process of creating history. Landscape is a character in the process" (p. 105-106). More importantly, he emphasizes the multivocality of Caribbean landscape "against the monolingual imperialism inherent from the West" (p. 150). For Glissant (1999), Caribbean history is characterized by "ruptures" and "brutal dislocation" (p. 61-62). I will draw on Glissant's theorization to investigate sites of rupture and erasure in Naipual's representation of Caribbean plantation landscape.

\section{Analysis and Discussion:}

The Caribbean writer, V. S. Naipaul (2002) inscribes his thoughts on Caribbean landscape and seascape while sojourning across the infamous Middle Passage, a water pathway stigmatized with a history of slavery and violence. The Middle Passage is associated with the uprootedness and forced migration of African slaves to the Caribbean plantations by European colonizers. Naipaul emphasizes the historical violence associated with the plantations and the sea as two sites commemorating a long history of colonization, fear, and loss.

In The Middle Passage (2002), Naipaul very clearly articulates his position towards the sugar plantation both as a site and a practice. He states: "I had never liked the sugarcane fields. Flat, treeless, and hot, they stood for everything I had hated about the tropics and the West Indies" (p. 56). For Naipaul, as for many Caribbeans, the sugar plantation encapsulates memories of violence interwoven into the natural landscape. As a postcolonial discursive intervention, The Middle Passage (2002) has contributed to positioning knowledge from below, by telling the unheard stories of the colonial legacy of the sugarcane. "The sugarcane" confirms Naipaul (2002), "is an ugly crop and it has an ugly history" (p. 118). Naipaul's interaction with nature and the uniformity of his position despite the diverse places he visits, according to G. Huggan and H. Tiffin (2011), is deeply influenced by "the originary trauma of the Middle Passage, whose burden of cultural memory is mapped onto a series of ravaged 


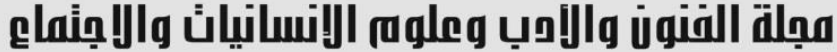

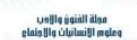

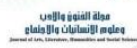

Journal of Arts, Literature, Humanities and Social Sciences www.jalhss.com

Volume (65) - February 2021
العدد (65) - فبراير 2021

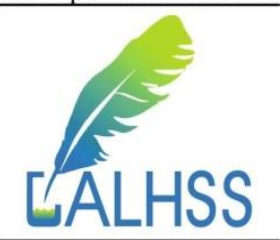

geographies, objective correlatives for the writer's repeatedly self-advertised 'colonial nerves"” (p. 113). Given that, for Naipaul, "nature is to be hated properly" (Huggan \& Tiffin (2010, p. 113). In the Caribbean collective unconscious, the sugarcane has become a sign, signifying an environmental disruption by foreign powers and an economic industry stigmatized with enslavement.

A major concern of Naipaul's discursive return to the Caribbean is to highlight the evils of the latifundia and the violence inherent in the plantation system. Canecultivation is very consuming and the machinery required for its refinement is highly expensive. For the colonizing power, slaves offer a cheap alternative. African slaves and indentured Indians have been transported to work in the plantations under very poor conditions and harsh measures of surveillance and control. In The Middle Passage, the narrator describes the latifundia as "a colonial society within a colonial society: a double confinement" (Naipaul, 2002, p. 118). Naipaul's narrative (2002) traces the colonial history of sugarcane back to the arrival of the European traveller, Columbus on the West Indies, affirming that " $[\mathrm{t}]$ here is slavery in the vegetation ... in the sugarcane, brought by Columbus on that second voyage when, to Queen Isabella's fury, he proposed the enslavement of the Amerindians" (p.180). The sugarcane plantation represents a colonial enclave of white masters violently dominating a community of labourer including African slaves and indentured Indians. The architecture of the plantation is carefully designed in ways that enable colonial planters to maintain high measures of surveillance and control over the landscape and the labor slaves (Hauser \& Hicks 2007). The Labor populations are contained in enclosed cells to eliminate opportunities of resistance and disobedience. In Naipaul's The Middle Passage (2002), the narrator records his observations of the "clusters of workers" houses that can be seen from the air, in the midst of the field" and "regularly intersected by ruler-straight irrigation ditches" (p. 117). This pattern resonates through the narrative whenever the observer is caught by the familiar scene of "sugarcane fields, intersected by ruler-straight ditches" that look like "machine-made carpets" (Naipaul, 2002, p. 86-87). These knowable patterns of slave enclosures and rows of crops, mediated and regulated by the planters' residence, according to J. Sharp's (2009) designation, conform to Foucault's model of the panopticon to facilitate consistent surveillance.

The Caribbean Landscape seems to be manipulated to reflect a site of ethnic divide. According to Naipaul, slavery is deeply entrenched in the land and its violent history has left permanent marks on its ecological structure. To the traveller, in Naipaul's narrative, "a clump of cashew trees marks the site of an Amerindian village," while in Jamaica, "a clump of star-apple trees marks the site of a slave provision ground" (2002, p. 180). Different ethnic spaces are marked by different plant types. The land has been unjustly divided; while fertile lands have been circumscribed for colonial plantations, poor and mountainous plots are given to slaves to grow their own food. Elsewhere in the narrative, "the cool coconut groves," to the traveller "announced Coronie" (Naipaul, 2002, p. 185). The Middle Passage (2002) 


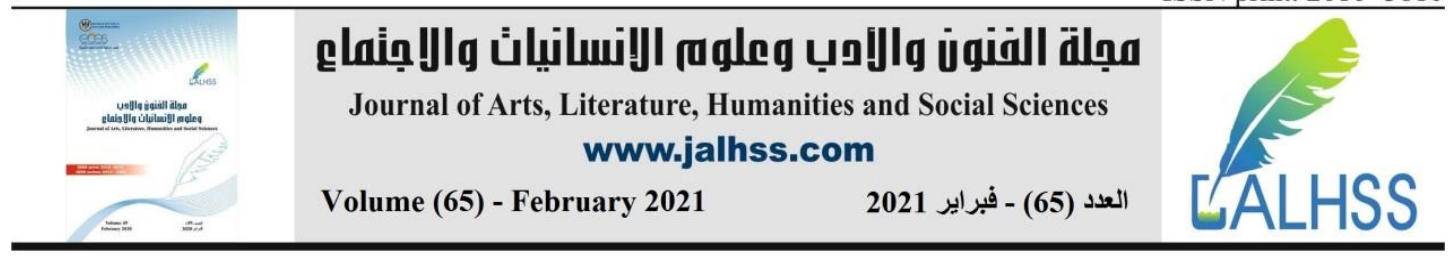

shows how a colonial plantation-based system is deeply entwined into the natural elements of the land. Biotic features have become sites of division, signifying the geopolitical space in which they grow, and bordering ethnic groups. Naipaul's representation recovers the Caribbean islands from the dictates of a colonial system profoundly interwoven into the land.

The derogatory history of the plantations is not only related to its entrenchment in slavery and violence but also to its lack of a real impact on the progress and sustainable development of the land, its native community and culture. Naipaul (2002) observes how "The history of the islands can never be satisfactorily told. Brutality is not the only difficulty. History is built around achievement and creation; and nothing was created in the West Indies" (p. 29). Since the collapse of the plantation system, Glissant (1999) contends, "it is neither replaced by industrialization nor by a complete restructuring of the economy" (p. 176). While Naipaul points to the lack of a historical narrative that recounts the untold stories of the silenced Caribbean, his travelouge offers a timely intervention of a postcolonial narrative of the Caribbean. Through this narrative, Naipaul questions any sustainable advancement or real history created by the plantation industry as it left no marks on the land but ruination and erasure.

The large-scale erasures forced upon the land for the purpose of sugar production involve measures of environmental and cultural disruption. These processes of erasure include deforestation, transplantation of the natural flora, use of chemical fertilizers and pesticides, to mention a few. The natural space has been replaced with a contrived landscape defined by a vegetation that is not endemic to the land. In his fictional narrative, Mimic Men, Naipaul (2001), articulates his rejection of the colonial configuration of the Caribbean landscape:

There was history in the vegetation we considered most natural and characteristic. About the bread-fruit and captain Bligh we all knew. He told me about the coconut, which fringed our beaches, about the sugarcane, the bamboo and mango. He told me about our flowers, whose colours we saw a fresh in the postcards which were beginning to appear in our shops. (p. 102)

The coconut tree, which has become "the cliche of the Caribbean," is a foreign plant that contributed to the manufacturing of the island landscape (Naipaul, 2002, p. 46). Being not endemic to the Caribbean land, sugarcane, like the coconut, is part of what A. Crosby (1986) has termed 'portmanaeu biota' (p. 89). These biotic migrants have been carried by Europeans to the colonies and contributed to their ecological transformation. The very vegetation that has been imported to the land, has came to define the Caribbean and introduce it to the world through postcards that tourists circulate, and, thus, perpetuate its colonial legacy. 


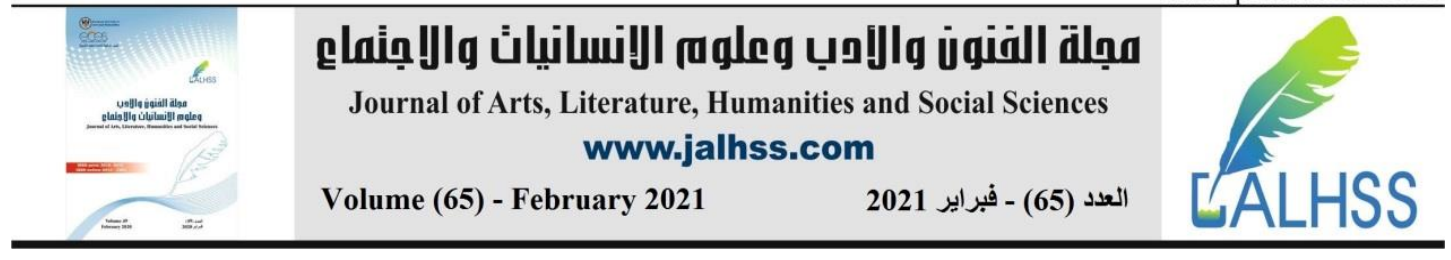

The ruination that the sugar plantations have inflicted on the land can be seen as signifying colonial intervention whilst simultaneously articulating the natural resistance of the land. While passing by the sugarcane fields in his return journey to Trinidad, the traveller in The Middle Passage reflects on how the sugarcane stands as a colonial site, a reminder of foreign domination:

I had never liked the sugarcane fields. Flat, treeless and hot, they stood for everything I had hated about the tropics and the West Indies. "Cane is bitter" is the title of a story by Samuel Selvon and might well be the epigraph of a history of the Caribbean. It is a brutal plant, tall and grass-like, with rough, razor-edged blades. I knew it was the basis of the economy, but I preferred trees and shades. (Naipaul, 2002, p. 56)

This extract from The Middle Passage is highly significant because it emphasizes the inextricable relation between the sugarcane and a history of colonial violence. This position is shared by other Caribbean writers. Naipaul makes a clear and direct reference to Sam Selvon's short story, entitled 'Cane is bitter,' highlighting the link between the cane and bitterness in cultural memory, and how this title can best represent the history of the West Indies. Cane is bitter for all the African slaves and indentured Indians uprooted from their colonies to work in the plantations, it is bitter for the poverty, hard labour, and dehumanization they experienced in the plantation. The extract continues with the traveller reporting a change in perception as he observes:

Now, in the uneven land of central and south Trinidad, I saw that even sugarcane could be beautiful. On the plains just before crop-time, you drive through it, walls of grass on either side; but in rolling country you can look down on a hillside covered with tall sugar-cane in arrow; steel-blue plumes dancing above a grey-green carpet, grey green because each long blade curves back on itself, revealing its paler underside. (Naipaul, 2002, p. 62)

Naipaul asserts in the preface to the first edition of this travelogue that he was commissioned by the Tindidad and Tobago Government to write a book on the region, and received a three-month scholarship for the visit. Eric William, then the Prime Minister, suggested expanding the geographical frame to include other Caribbean islands in the book (Naipaul 2002 \& Thieme 1982). The 'Now' in the above extract signifies an immediacy relevant to the time frame of the author's actual sojourn in the island. In 1962, Naipaul returned to Trinidad, revisiting the Caribbean islands for the purpose of writing The Middle Passage, first published in 1962 and republished in 2002. The year 1962 is very important in the history of Trinidad as it marks the year of independence. The above quote records Naipaul's observation in the immediate aftermath of independence. Only then can the returning traveller see beauty in the decolonized sugarcane plantations. The previous emphasis on the manufactured landscape of the plantation is now replaced with a closer observation of 


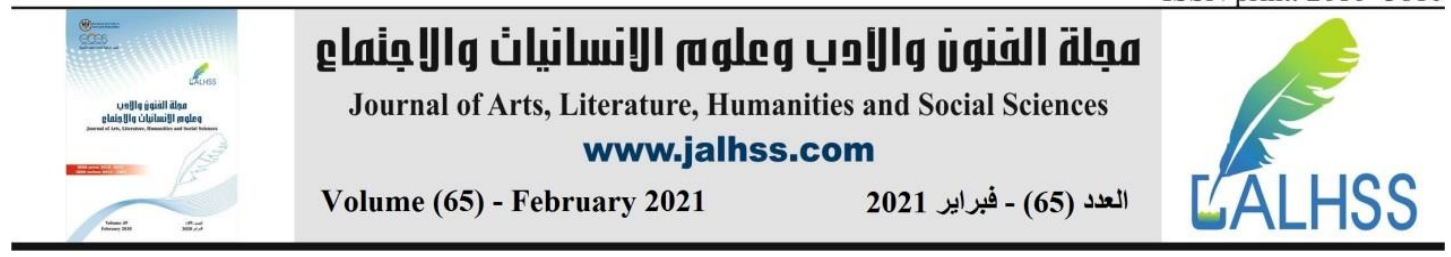

the fields in relation to the nature of the land, appreciating the diversity of the scene of cane trees on the plains from that of canes in rolling country. The liberation of Trinidad has liberated the viewer's perception, signifying rupture from the continuity of colonial hegemony.

Naipaul's engagement with ruins and decay in The Middle Passage (2002) reveals his commitment to narrate the local (hi)story of cane-cultivation, emphasizing its ongoing "imperial ruination" (p. 91). The narrative abounds with descriptions of decay and ruin. The savannah landscape turned to a "burning wasteland," with lunar mountains and black grounds (Naipaul, 2002, p. 98). While roaming in British Guiana, the traveller comments on the "decadent railways" (p. 117). A significant indicator of ruination is the Bagasse, the ruins of the sugarcane, following the abandonment of the plantation. The Bagasse along with the rusted remains of the refinery factories can be seen as sites that contribute to an aesthetic of ruin and decay in the Caribbean. In his novel, The Mimic Men (2001), Naipaul, however, makes a more direct reference to the ruins of slave plantations and the decaying brick walls of the sugar factory. Departing from the romanticization of the plantation, L. PravisiniGebert (2015) explores how local artists have manipulated debris in their visual arts by using Bagasse as a symbol of colonial ruination. Through this aesthetic of ruin and decay, Naipaul negotiates rupture in the history of plantation-based colonization. Furthermore, the chaotic growth of "walls of grass" in the fields after being abandoned by the colonizer signifies a natural resistance to the order enforced upon the land. The land seems to revolt with its natural flora, marking a form of natural resistance and a return to pre-colonial conditions.

While roaming across lands commonly known as savannah and cattle country, Naipaul expresses his thoughts about what he calls 'Nature's Mimicry' (Naipaul, 2002, p. 98). He conceptualizes the deceptive effect of the scene as it suggests, to the viewer from afar, a carefully tended orchard. However, a closer look would reveal a neglected land populated with "ant castles" and "sandpaper trees" (Naipaul, 2002, p. 98). Despite the negligence that has turned the place to a "burning wasteland" (Naipaul, 2002, p. 98), its non-human elements continue to mimic a form of order that only a West Indian collective unconscious is familiar with.

The seascape in Naipaul's narrative has a negative threatening effect against which the islands and the plantations need to be protected. In The Middle Passage, the sea forms a natural threat to "the fertile coastal strip" of British Guiana (Naipaul, 2002, p. 117). The topography of "being below sea-level" makes the plantations susceptible to the threats posed by surrounding water spaces, and requires efforts to protect them from the sea and the floods of the rivers in the region (Naipaul, 2002, p. 117). A similar position against the sea is powerfully articulated in Naipaul's fictional narrative The Mimic Men, originally published in 1967, five years after The Middle Passage. The protagonist of the novel, Ralph Singh, echoes the traveller's pronounced fear of the destructiveness of the sea: 


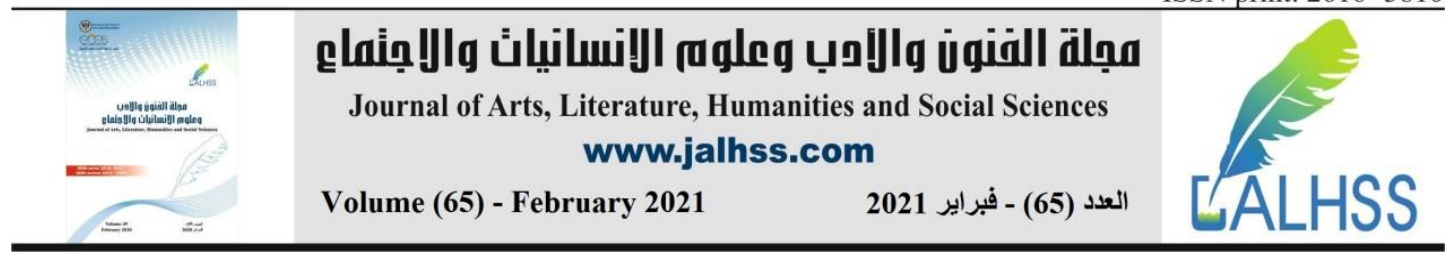

The sea broke on us almost without warning. Only a height of sky and a quality of openness behind the tops of trees suggested that a little way beyond there was no more land. And then, at the end of an avenue of coconut trees, was the living, destroying element, almost colourless at this distance [...] Not my element. I preferred land; I preferred mountains and snow. (Naipaul, 2001, p. 108)

All types of topography seem much safer and harmless than the 'coulourless', 'destroying element' of the sea. To the Caribbean collectivity, the destructiveness of the sea poses a natural threat not only to the land but also to the slaves who were forced to migrate from their native lands and face loss and death while crossing the Middle Passage to the Caribbean islands. There is history in the vegetation and there is history as well buried under the sea. The dead bodies under the sea bear witness to the atrocity linked with this economic system. Naipaul's pronounced position towards the sea takes a much deeper meaning when his travelling persona describes the West Indies as the vast, engulfing and brutally consuming sea of the European continent:

The European has been described as Europe's other sea, the Mideterranean of the New World. It was a Mediterranean which summoned up every dark human instinct without the complementary impulses towards nobility and beauty of older lands, a Mediterranean where civilization turned satanic, perverting those it attracted. (Naipaul, 2002, p. 201)

What appears to be a peaceful tourist destination, has long been "a wasteful consumer of men through more than three centuries" (Naipaul, 2001, p. 201). Against the emergent discourse of tourism in postcolonial islands, The Middle Passage (2002) negotiates the dehumanizing erasure attached to the European scramble to the West Indies, including: "the aboriginal population of some millions wiped out; the insatiable plantations: 300,000 slaves taken to Surinam [...]; the interminable wars: 40,000 British soldiers dead between 1794 and 1796 alone" (p.201).

The Caribbean fear of the destructiveness of the sea is translated into the common metaphors of ship and shipwreck in their literary expression. The Middle Passage opens with scenes from the Spanish ship, Francisco Bobadilla, that accommodates a collectivity of people from different socio-geographical contexts and carries the traveller back to the West Indies. According to P. Gilroy (1993), the ship is a very important medium that signifies "the movement of key cultural and political artifact" (p. 4). In the particular Caribbean context, De Ferrari (2012) establishes links between the ship and the plantation as "spatio temporal matrices of a distinctively Caribbean mode of existence" (p. 187). The opening scene of Naipaul's travel narrative features the ship as "a micro-cultural, micro-political system in motion" (p. 4), enunciating a site at the intersection of seascape and landscape. Its historicity is 


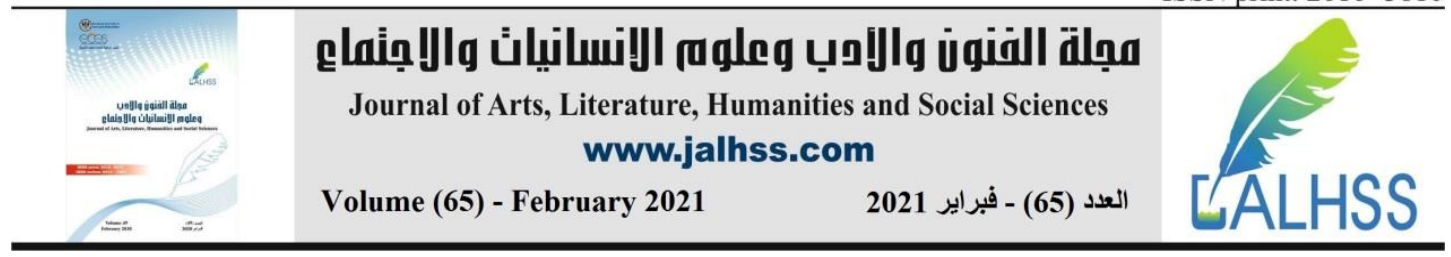

deeply connected to the sea routes of the middle passage and the roots of biotic elements arriving in the islands with the European colonizers and the uprooted slaves.

Concomitant to erasure are the familiar tropes of emptiness and vastness in Naipaul's description of the Caribbean land. However, this emptiness is not natural, but man-made as it has been inflicted by European colonization. Naipaul has unsettled and reversed the European conception of terra nullius, which forms a familiar trope in colonialist discourse realized in negating the Other's land by representing its emptiness and aridity. The hegemonic practice of dominating a foreign land, to grow foreign crops for the economic prosperity of the colonizer and the desolation of the natives, have left marks of ruin rather than development on both the land and the people. In The Middle Passage (2002), emptiness is reconfigured as the legacy of a plantation-based colonialism. Ironically, this emptiness is inextricably connected with the sugarcane industry; cutting woods has been central to clear space for more plantations. The traveller describes British Guiana as "a land of temporary forest clearings" (p. 121). Overwhelmed by emptiness, he articulates his thoughts on the ecological alteration that this practice has imprinted on the land:

And emptiness. Fly to the interior. First you go over the sugarcane fields beside the brown Demerara River. Abruptly the fields stop and bush begins; and in the bush there are little irregular areas of timorous destruction-indicating attitudes you will learn to associate with British Guiana- where forest has turned to marshland, for the soil here is poor and hardwood trees cannot easily be made to grow again. (Naipaul, 2002, p. 87)

The above quote signifies the ecological damage inflicted on the land by the colonizer. Because of continued massive deforestation, trees cannot grow again in the same plot of land, and the forests of the pre-colonial time have turned to untended marshlands. While this vastness seems incomprehensible to the travelling persona, the narrative has established direct connections between forest clearings and colonialist excavations of natural resources. Although the harm inflicted on the land cannot be undone, deforestation has not made the West Indies a wealthy state. Most of the treasures are still buried in the infertile land:

'Vast,' too, are the natural resources; these are invariably 'untapped.' The impression created is that forests have simply to be cut down for a wealthy new state to grow. In fact, a good deal of the untapped interior rests on infertile white sand, and the problem of reafforestation has yet to be solved. (Naipaul, 2002, p. 97-98)

Colonial exploitation of the land has contributed to the deterioration of its ecological fertility. 


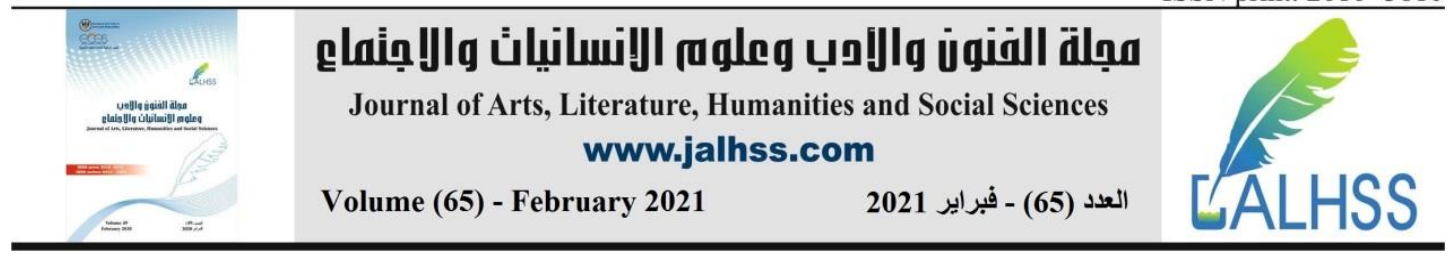

Home gardening in the Caribbean can be seen as a form of rupture and discontinuity in reaction to the colonial plantation. The Caribbean locals turn to plant their own gardens at home, assuming self-sufficiency. While travelling through Surinam, the narrator of The Middle Passage (2002) observes, with mush pride, how "each hut had its provision garden" (p. 185). This practice signifies an act of resistance to colonial powers. L. Perfitti (2007) investigates gardening in SchwartsBart's 1972 novel and recognizes it as a "central form of resistance to the plantation" in the West Indies (p. 95). As a "site of negotiation," argues Perfitti (2007), the garden forms a space that "enables black islanders to rethink their place in history and reclaim their relation to land and community" (p. 98). Along the same line, DeLoughrey (2004) positions Jamaica Kincaid's The Garden in the context of a postcolonial tradition linking gardening and writing, suggesting ways of reconfiguring the "dialectical split" between nature and culture (p. 305). For Naipaul, the local gaze of the travelling persona endows his postcolonial perspective with immaculate and sensitive interaction with the natural scene and its ideological implications.

While engaging with sites of rupture and erasure associated with the plantation landscapes, the travel narrative reflects the tension between the local and the visitor's perspectives. Naipaul can be seen as both a local Trinidadian, returning to the land after years of absence, and a foreign observer influenced by his cultural experience in Western diaspora. While consciously rejecting the gaze of the affluent tourist, the travelogue, as Thieme (1982) suggests, embraces a plethora of voices including the "Victorian traveller," "the enfeebled explorer," and the "evocative imagistic" voice of the novelist (p. 148). This multiplicity and lack of a uniform voice, argues Thieme (1982), is both a strength and a weakness as it enriches the dialogism and centrifugality of the narrative, but fails to develop a resolution to the tone. S. Ozawa (2012) takes Thieme's argument further as he attributes an enabling power to that tension for making it possible to see the local scene from the perspective of a "detached observer" (p. 4) while simultaneously ascribing the authority and credibility of the local to his observation. The sojourn in The Middle Passage, Ozawa (2012) contends, encapsulates the writer's transitional journey from a "West Indian writer" to a "controversial chronicler of the chaotic postcolonial world" (p. 8). Drawing on Glissant's (1999) theorization, I read the dialogism inherent in Naipaul's construction of the Caribbean landscape as a natural reflection to the postcolonial multivocality of its historicity. The complex interrelatedness between the politics and poetics of the Caribbean landscape produces palimpsests of pre-colonial, colonial, and post-colonial histories, which evoke the heteroglossia of Naipaul's narrative.

In The Middle Passage (2002), Naipaul notes the failure of local visual arts to represent the nature of the land. Given the lack of authentic representations by native painters, unlearning Eurocentric configurations through active experience of the Caribbean landscapes becomes increasingly imperative as Naipaul (2002) contends: "Everyone has to learn to see the West Indies tropics for himself. The landscape has never been recorded, and to go to the Trinidad Art Society Exhibition is to see how 


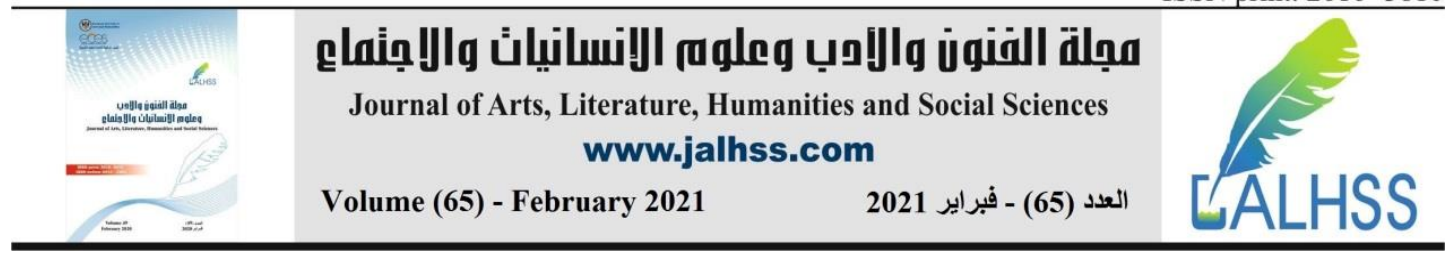

little local painters help" (p. 63). The titles of these paintings, the scenes captured, and the colours of beach sites contribute to the production of picturesque characters and landscapes that reflect the vision and the taste of the tourist instead of the local gaze of the native Trinidadian. To the returning traveller of The Middle Passage, the displayed paintings, deprived of "the depth of the sky, the brilliancy of light, the insubstantiality of color in the tropics," (Naipaul, 2002, p. 63) fail to capture the true nature of this space. "The more gifted painters have ceased to record the landscape: the patterns of the leaves are too beguiling. In art, as in almost everything else, Trinidad has in one step moved from primitivism to modernism" (p. 63). E. Glissant (1999) has distinguished this mode of fast irruption into modernity from the gradual development into matured modernity, claiming that "The sudden irruption into modernity created a schism between nature and culture in the region that its literature sought to bridge" (p. 146). Neither the sublime nature of the landscape nor the power politics underlying it has been refracted in local visual arts, hence Naipaul's discursive intervention can be seen as an attempt to bridge this epistemic gap.

\section{Conclusion}

The Middle Passage contributes to a tradition of postcolonial re-inscriptions of the West Indies, which repositions knowledge from below and promotes the disentanglement of the Caribbean islands from colonialist constructions. The narrative recounts the travel of a "derelict man in a derelict land," emphasizing the environmental and historical desolation of the landscape (Naipaul, 2002, p. 187). In Naipaul's travel narrative, the plantation landscapes appear to be entrenched in colonial history, monumentalising environmental violence, colonial hegemony, and racial segregation. Naipaul's literary configuration of the plantation landscapes in the West Indies represents the ruptures and brutal dislocations inflicted by European colonialism. While the land bears witness to the evils of ecological alteration, the panopticon architecture of the sugarcane plantations maintains colonial surveillance over the slave population. In this particular geopolitical and discursive context, human and non-human elements of landscape and seascape form a dialectical relation that continue to assert the agency of colonial and postcolonial interventions in the palimpsest of the West Indies topography.

\section{References:}

1. Armstrong, D. V \& Hauser, M. W. (2009). A Sea of Diversity: Historical Archaeology in the Caribbean. In International Handbook of Historical Archaeology, T. Majewiski \& D. Gaimster (eds.), Springer Science, 583-612. DOI 10.1007/978-0-387-72071-5-32

2. Crosby, A. (1986). Ecological Imperialism: the Biological Expansion of Europe, 900-1900, Cambridge: Cambridge University Press.

3. De Ferrari, G. (2012). The Ship, the Plantation, and the Polis: Reading Gilroy and Glissant as Moral Philosophy. Comparative Literature Studies, 49(2), Special issue: Comparative Perspectives on the Black Atlantic, 186-209. 


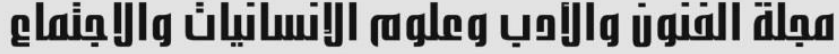 \\ Journal of Arts, Literature, Humanities and Social Sciences www.jalhss.com \\ Volume (65) - February 2021 \\ العدد (65) - فبراير 2021}

4. DeLoughrey, E. Didur, J. \& Carrigan, A. (Eds.). (2015). Global Ecologies and the Environmental Humanities: Postcolonial Approaches, New York \& London: Routledge.

5. DeLoughrey, E. (2004). Island Ecologies and Caribbean Literatures. Royal Dutch Geographical Society KNAG, 95(3), 298-310.

6. Gilroy, P. (1993). The Black Atlantic: Modernity and Double Consciousness, London: VERSO.

7. Glissant, E. (1999). Caribbean Discourse: Selected Essays. Trans. J. Michael Dash, Charlottesville: University Press of Virginia.

8. Hauser, M. W. \& Hicks, D. (2007). Colonialism and Landscape: Power, Materiality and Scales of Analysis in Caribbean Historical Archaeology. In D. Hicks, L. McAltackney \& G. Fairclough (Eds.) Envisioning Landscape: Situations and Standpoints in Archaeology and Heritage (pp. 251-274). Walnut Greek, CA: Left Coast Press.

9. Huggan, G \& Tiffin, H. (2010). Postcolonial Ecocriticism: Literature, Animals, Environment, London: Routledge.

10. Mitchell, W. J. T. (2002). Imperial Landscapes. In Mitchell, W. J. T. (ed.), Landscape and Power (pp. 1-34). Chicago: University of Chicago Press.

11. Naipaul, V. S. (2002). The Middle Passage: The Caribbean Revisited. New York: Vintage Books. epub

12. Naipaul, V. S. (2001). The Mimic Men. New York, Vintage Books. mobi

13. Ozawa, S. (2012). On Naipaul's Cultural Position in The Middle Passage. CLCWeb: Comparative Literature and Culture, 14(5). http://docs.lib.purdue.edu/clcweb/vol14/iss5/

14. Paravisini-Gebret, L.(2015). Bagasse: Caribbean Art and the Debris of the Sugar Plantation. In E. DeLoughrey, J. Didur, \& A. Carrigan (Eds.), Global Ecologies and the Environmental Humanities: Postcolonial Approaches (pp. 73-94). New York \& London: Routledge.

15. Perfetti, L. ( 2007). The Postcolonial Land that Needs to be Loved: Caribbean Nature and the Garden in Simone Schwartz-Bart's Pluie et Vent sur Telumee Miracle. Interdisciplinary Studies in Literature and Environment, 14(1), 89105.

16. Sharp, J. (2009). Geographies of Postcolonialism: Spaces of Power and Representation. SAGE.

17. Thieme, J. (1982). Authorial Voice in V. S. Naipaul's The Middle Passage. Prose Studies: History, Theory, Criticism, 5(1), 139-150. DOI: $10.1080 / 01440358208586159$ 